\title{
The Pig as a Translational Model for Respiratory Immunology Research
}

\author{
Marco A Vega-López* \\ Infectomics and Molecular Pathogenesis Department, Mucosal Immunobiology Laboratory, Mexico
}

Submission: April 7, 2017; Published: April 27, 2017

*Corresponding author: Marco A Vega-López, Senior Research Scientist, Centro de Investigación y de Estudios Avanzados del Instituto Politécnico Nacional, Infectomics and Molecular Pathogenesis Department, Mucosal Immunobiology Laboratory, Mexico City, Email: mavega@cinvestav.mx

\section{Opinion}

Respiratory diseases in the world had increased dramatically in recent years. Cancer, COPD, allergies and a wide spectrum of re-emergent infectious diseases have challenged the capabilities of institutional health services, not only in developing countries but also in first world nations. The periodical release of sanitary alerts from the WHO should drive attention to the increased need of practical and effective solutions to those problems.

And it is in that sense that immunologist should recognize the lack of knowledge on how the immune system in the lung deals with many of these maladies. As a consequence, therapeutics and prophylaxis are, in many cases, just palliative measures which do not control or eliminate the problem.

Research in mucosal immunology is relatively recent, compared with traditional systemic knowledge. This should not represent major problem if the mucosal immune system follows the same pathways systemic immunity does. Unfortunately this is not always the case. Vaccination is a good example of this. Systemic (mainly intramuscular) vaccination has demonstrated to be very effective in inducing humoral and even cellular immune responses. The injection of the antigen into a highly vascularized tissue guarantees its arrival to the lymphoid organs, which will develop the whole array of immune responses in a short period. Problems as tolerance induction, uncertain administered dose and premature degradation of the antigen $(\mathrm{Ag})$ are minimized. Mucosal immunization, on the contrary, deals with the tendency to induce tolerance to Ags and it is almost impossible to guarantee that the administered dose reach the immune organs due to different rates of Ag degradation.

Another problem to overcome is the limited access to mucosal human samples where to perform experiments on structure, development, function and regulation. Rodents have been successfully used to reveal some of the particular features mucosal immunology have compared to systemic immunity. The presence of inductive and effector sites is one of the features which differentiate mucosal from systemic immunity. However, questions as structure and development of the respiratory immune system are difficult to address in rodents. Important differences in size, incomplete development at birth and the constitutive expression of nasal and bronchial lymphoid tissues difficult the extrapolation of results to human beings. Fortunately enough, other animal models have been developed with particular success. One of them, the pig, is considered a suitable model for human infectious and degenerative diseases $[1,2]$, medical training [3] and respiratory medicine [4]. We have used the pig to elucidate some basic questions as the development of lung immune cells after birth [5], the appearance and function of the lung IgA secretory system [6] and the role of maternal immunity on the respiratory immune response to early mucosal vaccination [7]. The information obtained from these reports allowed us to understand more closely the reasons behind the increased susceptibility of young organisms to respiratory diseases, to identify critical stages in mucosal development where vaccination may be needed and the role of maternal immunity to compensate the transient poor immunological performance of the young animal in both systemic and mucosal compartments.

Issues as the effective development of humoral and cellular immune responses at mucosal sites after vaccination, the understanding of how respiratory allergies develop in the respiratory system, the search for early induction of immunity in the young and the modulation of the tolerance/immunity dichotomy at mucosal sites, are now intensively investigated, using models at pre-clinical studies. The results of these intriguing questions will be surely boosted by the use of translational models as the pig.

\section{References}

1. Meurens F, Summerfield A, Nauwynck H, Saif L, Gerdts V (2012) The pig: a model for human infectious diseases. Trends Microbiol 20(1): 50-57.

2. Cruz R, Ramírez C, Rojas OI, Casas-Mejía O, Kouri JB, et al. (2016) The Pig as an Osteoarthritis Translational Research Model. J Ost Arth 1:1 
3. Eiji Kobayashi, Shuji Hishikawa, Takumi Teratani, Alan T Lefor (2012) The pig as a model for translational research: overview of porcine animal models at Jichi Medical University. Transplantation Research 1(1): 8.

4. Judge EP, Hughes JM, Egan JJ, Maguire M, Molloy EL et al. (2014) Anatomy and bronchoscopy of the porcine lung. A model for translational respiratory medicine. Am J Respir Cell Mol Biol 51(3): 334-343.

5. Balam-May AJ, Ramírez-Estudillo C, Lazo-Vázquez G, Vega-López MA (2014) Postnatal development of lung $\mathrm{T}$ lymphocytes in a porcine model. Lung 192(5): 793-802.
6. E Guzman-Bautista ER, Ramirez-Estudillo MC, Rojas-Gomez OI, VegaLopez MA (2015) Tracheal and bronchial polymeric immunoglobulin secretory immune system (PISIS) development in a porcine model. Dev Comp Immunol 53(2): 271-282.

7. Guzman-Bautista ER, Garcia-Ruiz CE, Gama-Espinosa Al, RamirezEstudillo C, Rojas-Gomez OI (2014) Effect of age and maternal antibodies on the systemic and mucosal immune response after neonatal immunization in a porcine model. Immunology 141(4): 609616

\section{Your next submission with Juniper Publishers will reach you the below assets}

- Quality Editorial service

- Swift Peer Review

- Reprints availability

- E-prints Service

- Manuscript Podcast for convenient understanding

- Global attainment for your research

- Manuscript accessibility in different formats

( Pdf, E-pub, Full Text, Audio)

- Unceasing customer service

Track the below URL for one-step submission https://juniperpublishers.com/online-submission.php 